\title{
Relationship between serum vitamin $D$, adipokines and dyslipidemia in type 2 diabetes mellitus
}

\begin{abstract}
Background: Type 2 diabetes mellitus (T2DM) is related to high risk for cardiovascular disorders especially if it is associated with deficiency of vitamin D.

Objective: The aim of our study was to measure the relationship between serum vitamin $\mathrm{D}$, dyslipidemia and adipokines in noninsulin dependent diabetes mellitus (NIDDM).

Material and Methods: Two hundred obese subjects (136 women and 64 men) with T2DM, the mean of their body mass index was $30.84 \pm 3.26 \mathrm{Kg} / \mathrm{m} 2$ and they are taking oral hypoglycemic agents as pioglitazone and/or metformin who are selected from outpatient diabetic clinic of the King Abdulaziz Teaching Hospital, Jeddah, Saudi Arabia. Renal insufficiency, heart failure, smoking, pregnant women, viral hepatitis and vitamin D supplement were the exclusion criteria in this study. Participants enrolled in one of the 3 groups according to serum vitamin D status: group (I) sufficient vitamin $\mathrm{D}<20 \mathrm{ng} / \mathrm{ml}$, group (II) insufficient vitamin $\mathrm{D}=20-30 \mathrm{ng} / \mathrm{ml}$ and group (III) deficient vitamin $\mathrm{D}>30 \mathrm{ng} / \mathrm{ml}$.
\end{abstract}

Results: Concerning variables of the three groups, there were significant higher mean values of TC, TG, LDL and leptin in group (III) than both group (I) and (II) as well as lower mean values of HDL and adiponectin in group (III) than group (I) and (II). However, serum level of vitamin D revealed direct correlation with HDL and adiponectin \& a negative correlation with TC, TG, LDL \& leptin in all groups.

Conclusion: There was relationship between vitamin D status, dyslipidemia and adipokines in Type 2 diabetes mellitus.

Keywords: adipokines, dyslipidemia, noninsulin dependent diabetes mellitus, Vitamin D
Volume 3 Issue 2 - 2018

\section{Essam $\mathrm{H}$ Jiffri}

Department of Medical Laboratory Technology, Faculty of Applied Medical Sciences, King Abdulaziz University, Saudi Arabia

Correspondence: Essam H Jiffri, Department of Medical Laboratory Technology, Faculty of Applied Medical Sciences, King Abdulaziz University, P.O. Box 80324, Jeddah, 21589, Saudi Arabia,Email ejiff@hotmail.com

Received: June 06, 2018 | Published: June 25, 2018
Abbreviations: ANOVA, analysis of variance; NIDDM, noninsulin dependent diabetes mellitus; T2DM, type 2 diabetes mellitus; HDL, high density lipoprotein

\section{Introduction}

Type 2 diabetes mellitus (T2DM) is a continuous growing medical problem affect about 400 million in 2013, this number will reach about 600 million by 2035, while the developing countries have the highest rate of prevalence for NIDDM. ${ }^{1}$ WHO asssigned diabetes as an epidemic disease of 21 century. 2,3

Noninsulin dependent diabetes mellitus (NIDDM) is a principal cardiovascular disorders risk factor for that makes NIDDM is a main cause for morbidity and mortality around the globe. ${ }^{4}$ Diabetic dyslipidemia, hyperglycemia, insulin resistance, systemic inflammation and abnormal levels of adipocytokines are the main risk factors for cardiovascular dysfunction.,

Vitamin D regulates many body systems function as bone and adipocyte metabolism. ${ }^{7,8}$ Obesity is usually associated with vitamin $\mathrm{D}$ deficiency, which induces insulin resistance and increases the risk for NIDDM. ${ }^{9-12}$ Vitamin D deficiency, which is considered as a neglected risk factor for cardiovascular disorders among patients with NIDDM $^{13-15}$ and affect about billion subjects around the globe. ${ }^{16}$

The aim of our study was to measure relationship between serum vitamin $\mathrm{D}$, dyslipidemia and adipokines in noninsulin dependent diabetes mellitus (NIDDM).

\section{Material and methods}

\section{Subjects}

Two hundred obese subjects (136 women and 64 men) with NIDDM, the mean of their body mass index was $30.84 \pm 3.26 \mathrm{Kg} /$ $\mathrm{m}^{2}$, they are taking oral hypoglycemic agents as pioglitazone and/ or metformin who are selected from diabetes outpatient clinic of King Abdulaziz Teaching Hospital, Jeddah, Saudi Arabia. Renal insufficiency, heart failure, smoking, pregnant women, viral hepatitis and vitamin D supplement were the exclusion criteria in this study. Participants enrolled in one of the 3 groups according to serum vitamin D status: group (I) sufficient vitamin $\mathrm{D}<20 \mathrm{ng} / \mathrm{ml}$, group (II) insufficient vitamin $\mathrm{D}=20-30 \mathrm{ng} / \mathrm{ml}$ and group (III) deficient vitamin $\mathrm{D}>30 \mathrm{ng} / \mathrm{ml}$. All participants signed a consent before sharing in the study.

\section{Laboratory measurements}

Ten milliliters venous blood samples were taken after 10 hours of overnight fasting from all participants to measure:

a) Serum vitamin D measurement: Elisa Kit; DiaSorin, Stillwater, $\mathrm{MN}$, USA was used to measure serum level of vitamin D. 
b) Serum adiopkines markers measurement: Human Leptin Quantikine ELISA Kit (R\&D Systems, Minneapolis, MN, USA was used for assessment of leptin, while Acrp30 Quantikine ELISA Kit (R\&D Systems was used for adiponectin measurement.

\section{Statistical analysis}

Analysis of results was conducted with SPSS version 23 (Chicago, USA). All variables were presented in mean $\pm \mathrm{SD}$, one way ANOVA was the statistical method used for comparing quantitative variables between groups. Spearman's rank correlation test was used to measure the relation between serum vitamin D and dyslipidemia \& adipokines in NIDDM $(\mathrm{p}<0.05)$.

Table I Basic criteria of all participants

\begin{tabular}{|c|c|c|c|c|}
\hline Variables & Group (I) & Group (II) & Group (III) & $P$ value \\
\hline Age (year) & $53.29 \pm 5.16$ & $55.5 I \pm 4.82$ & $54.98 \pm 5.74$ & 0.528 \\
\hline $\mathrm{BMI}\left(\mathrm{kg} / \mathrm{m}^{2}\right)$ & $31.38 \pm 3.37$ & $32.4 I \pm 3.28$ & $30.77 \pm 2.95$ & 0.182 \\
\hline Hemoglobin (gm/dl) & $\mid 2.76 \pm 1.21$ & $13.12 \pm 1.33$ & $13.46 \pm 1.17$ & 0.442 \\
\hline $\mathrm{SBP}(\mathrm{mmHg})$ & $136.15 \pm 16.19$ & $|39.54 \pm| 3.22$ & $|37.38 \pm| \mid .68$ & 0.131 \\
\hline $\mathrm{DBP}(\mathrm{mmHg})$ & $81.31 \pm 9.25$ & $80.27 \pm 7.24$ & $78.19 \pm 6.13$ & 0.165 \\
\hline HBAIc (\%) & $9.37 \pm 2.18$ & $8.69 \pm 1.76$ & $7.28 \pm 1.54$ & $0.027^{*}$ \\
\hline FBS (mg/dl) & $186.29 \pm 21.57$ & $|4| .43 \pm 16.72$ & $123.42 \pm 12.56$ & $0.008^{*}$ \\
\hline PPS (mg/dl) & $261.36 \pm 28.15$ & $203.25 \pm 22.68$ & $|65.37 \pm| \mid .24$ & $0.006^{*}$ \\
\hline
\end{tabular}

BMI, body mass index; SBP, systolic blood pressure; DBP, diastolic blood pressure; HBA Ic, glycated hemoglobin; FBS, fasting blood sugar; PPS, postprandial blood sugar; $\left(^{*}\right)$ indicates a significant difference between groups, $\mathrm{P}<0.05$.

Table 2 Comparison of variables between the three groups

\begin{tabular}{|c|c|c|c|c|}
\hline Variables & Group (I) & Group (II) & Group (III) & $P$ value \\
\hline $\mathrm{TC}$ (mg/dL) & $196.14 \pm 21.27$ & $188.26 \pm 18.39$ & $179.35 \pm 15.28$ & $0.001 *$ \\
\hline TG (mg/dL) & $121.91 \pm 17.22$ & $113.15 \pm 13.36$ & $94.27 \pm 11.15$ & $0.003^{*}$ \\
\hline $\mathrm{HDL}(\mathrm{mg} / \mathrm{dL})$ & $32.86 \pm 3.75$ & $38.73 \pm 4.14$ & $45.52 \pm 6.78$ & $0.009 *$ \\
\hline LDL (mg/dL) & $109.31 \pm|4.6|$ & $95.86 \pm 11.54$ & $89.14 \pm 9.15$ & $0.007^{*}$ \\
\hline Adiponectin $(\mu \mathrm{g} / \mathrm{ml})$ & $19.62 \pm 2.56$ & $22.43 \pm 3.21$ & $30.28 \pm 3.53$ & $0.028 *$ \\
\hline Leptin(ng/ml) & $32.47 \pm 3.14$ & $24.25 \pm 2.95$ & $|5.7| \pm 2.38$ & $0.013^{*}$ \\
\hline
\end{tabular}

TC, total cholesterol; TG, triglycerides; HDL-c, high-density lipoprotein cholesterol; LDL-c, low--density lipoprotein cholesterol; (*) indicates a significant difference between groups, $\mathrm{P}<0.05$.

Table 3 Spearman's rank correlation between vitamin D and lipid profile and adipokines in the three groups

\begin{tabular}{llll}
\hline Variables & Group (I) & Group (II) & Group (III) \\
\hline $\mathrm{TC}(\mathrm{mg} / \mathrm{dL})$ & $-0.638^{* *}$ & $-0.646^{* *}$ & $-0.722^{* *}$ \\
$\mathrm{TG}(\mathrm{mg} / \mathrm{dL})$ & $-0.514^{*}$ & $-0.618^{* *}$ & $-0.578^{*}$ \\
$\mathrm{HDL}(\mathrm{mg} / \mathrm{dL})$ & $0.613^{* *}$ & $0.593^{* *}$ & $0.632^{* *}$ \\
$\mathrm{LDL}(\mathrm{mg} / \mathrm{dL})$ & $-0.582 *$ & $-0.65 \mathrm{I}^{* *}$ & $-0.527 *$ \\
Adiponectin $(\mu \mathrm{g} / \mathrm{ml})$ & $0.539^{*}$ & $0.646^{* *}$ & $0.674 * *$ \\
Leptin $(\mathrm{ng} / \mathrm{ml})$ & $-0.654^{* *}$ & $-0.718^{* *}$ & $-0.698^{*}$ \\
\hline
\end{tabular}

Spearman's correlation was used $*, \mathrm{P}<0.05 * *, \mathrm{P}<0.0 \mathrm{I}$ 


\section{Discussion}

WHO stated that diabetes became an epidemic disease of $21^{\text {st }}$ century. ${ }^{2}$ However, T2DM is a global cause for morbidity and mortality. ${ }^{17}$ There are many studies reported vitamin D deficiency among patients with INDDM. ${ }^{18-20}$ Although, vitamin D has a regulating role in metabolism of bone and adipose tissue..$^{21-25}$ This study aimed to measure relationship between serum vitamin $\mathrm{D}$, adipokines and dyslipidemia in NIDDM.

The results of our study proved that secretion of leptin decreased when serum level of vitamin D is high in addition to an inverse relation between these variables. These results agreed with Amir et al. ${ }^{26}$ found a slight negative relationship between leptin and vitamin D among breast cancer women. In addition, Figuiredo-Dias \& Grethen et al., ${ }^{27,28}$ proved presence of inverse relationship between serum vitamin D and leptin among patients renal insufficiency and obese women. However, supplemental vitamin D reduced level of leptin in patients with hemodialysis. ${ }^{29}$ Reduced serum vitamin D may reduce the level of circulating calcium that induce hyperparathyroidism that in turn stimulates fat storage and lipogenesis and as a result enhanced adipocytes to secret leptin. ${ }^{30}$ However, our results proved that secretion of adiponectin increased when serum level of vitamin D is high in addition to a positive relation between these variables. These results agreed with Walker et al. reported that adding of vitamin D to growth medium enhanced secretion of adiponectin in mice. ${ }^{31}$ However, Feng et al., ${ }^{32}$ found that vitamin D inhibited expression of TNF- $\alpha$ mRNA that is pro-inflammatory cytokine that is a main inhibitor for adiponectin synthesis. Moreover, Breslavsky et al., ${ }^{33}$ stated that one year of supplemental vitamin D enhanced adiponectin secretion.

Concerning variables of the three groups, there were significant higher mean values of TC, TG, LDL and leptin in group (III) than both group (I) and (II) as well as lower mean values of HDL and adiponectin in group (III) than group (I) and (II). However, serum level of vitamin D revealed direct correlation with HDL and adiponectin \& a negative correlation with TC, TG, LDL \& leptin in all groups. Our results are consistent with several studies that measured cardiovascular risk in NIDDM patients from sunny countries. ${ }^{34,35}$ These findings can be justified if we considered blood lipid levels as the intervenient variable that act as a link between low vitamin D level and cardiovascular disorders in NIDDM. ${ }^{36-39}$

\section{Conclusion}

There was relationship between vitamin D status, dyslipidemia and adipokines in noninsulin dependent diabetes mellitus.

\section{Acknowledgments}

None.

\section{Conflict of interest}

Author declares no conflict of interest.

\section{References}

1. Guariguata L, Whiting DR, Hambleton I, et al. Global estimates of diabetes prevalence for 2013 and projections for 2035. Diabetes Res Clin Pract. 2014;103(2):137-149.

2. World Health Organization. Diabetes.
3. Farag YM, Gaballa MR. Diabesity: An overview of a rising epidemic. Nephrol Dial Transplant. 2011;26(1):28-35.

4. Bartels DW, Davidson MH, Gong WC. Type 2 diabetes and cardiovascular disease: reducing the risk. J Manag Care Pharm. 2007;13(2 Suppl A):S215.

5. Bakker W, Eringa EC, Sipkema P, et al. Endothelial dysfunction and diabetes: roles of hyperglycemia, impaired insulin signaling and obesity. Cell Tissue Res. 2009;335(1):165-189.

6. Lebovitz HE. Insulin resistance-a common link between type 2 diabetes and cardiovascular disease. Diabetes Obes Metab. 2006;8(3):237-249.

7. Chang, E, Kim Y. vitamin D insufficiency exacerbates adipose tissue macrophage infiltration and decreases AMPK/SIRT1 activity in obese rats. Nutrients. 2017;29:9(4)

8. Verstuyf A, Carmeliet G, Bouillon R, et al. Vitamin D: a pleiotropic hormone. Kidney Int. 2010;78(2):140-145.

9. Chagas CE, Borges MC, Martini LA, et al. Focus on vitamin D, inflammation and type 2 diabetes. Nutrients. 2012;4(1):52-67.

10. Devaraj S, Jialal G, Cook T, et al. Low vitamin D levels in Northern American adults with the metabolic syndrome. Horm Metab Res. 2011;43(1):72-74.

11. Ducloux R, Nobécourt E, Chevallier JM, et al. vitamin D deficiency before bariatric surgery: Should supplement intake be routinely prescribed? Obes Surg. 2011;21(5):556-560.

12. Grineva EN, Karonova T, Micheeva E, et al. vitamin D deficiency is a risk factor for obesity and diabetes type 2 in women at late reproductive age. Aging (Albany NY). 2013;5(7):575-581.

13. Cigolini M, Iagulli MP, Miconi V, et al. Serum 25-hydroxyvitamin D3 concentrations and prevalence of cardiovascular disease among type 2 diabetic patients. Diabetes Care. 2006;29(3):722-724.

14. Pittas AG, Lau J, Hu FB, et al. The role of vitamin D and calcium in type 2 diabetes. A systematic review and meta-analysis. J Clin Endocrinol Metab. 2007;92(6):2017-2029.

15. Lee JI, Oh SJ, Ha WC, et al. Serum 25-hydroxyvitamin D concentration and arterial stiffness among type 2 diabetes. Diabetes Res Clin Pract. 2012;95(1):42-47.

16. Ginde AA, Liu MC, Camargo CA. Demographic differences and trends of vitamin D insufficiency in the US population, 1988-2004. Arch Intern Med. 2009;169(6):626-632.

17. Global Burden of Diabetes. Diabetic Atlas. 5thed. Brussels (Belgium): International Diabetes Federation; 2011.

18. Cimbek A, Gürsoy G, Kirnap NG, et al. Relation of Serum 25-hydroxy vitamin D3 levels with insulin resistance in type 2 diabetic patients and normal subjects. Med Science. 2012;1(4):305-314.

19. Taheri E, Saedisomeolia A, Djalali M, et al. The relationship between serum 25-hydroxy vitamin $\mathrm{D}$ concentration and obesity in type 2 diabetic patients and healthy subjects. J Diabetes Metab Disord. 2012;11:16.

20. Maggi S, Siviero P, Brocco E, et al. vitamin D deficiency, serum leptin and osteoprotegerin levels in older diabetic patients: An input to new research avenues. Acta Diabetol. 2014;51(3):461-469.

21. Mutt SJ, Hyppönen E, Saarnio J, et al. vitamin D and adipose tissue-more than storage. Front Physiol. 2014;5:228.

22. Zhang Qiao, Shi Li xing, Peng Nian chun, et al. Serum 25(OH)D Level and parathyroid hormone in Chinese adult population: A crosssectional study in Guiyang Urban Community from Southeast of China. International Journal of Endocrinology. 2013;2013:7. 
23. Abbas MA. Physiological functions of vitamin D in adipose tissue. $J$ Steroid Biochem Mol Biol. 2017;165(Pt B):369-381.

24. Lorente Cebrián S, Eriksson A, Dunlop T, et al. Differential effects of 1_,25-dihydroxycholecalciferol on MCP-1 andbadiponectin production in human white adipocytes. Eur J Nutr. 2012;51(3):335-342.

25. Amir E, Cecchini RS, Ganz PA, et al. 25-Hydroxy vitamin-D, obesity, and associated variables as predictors of breast cancer risk and tamoxifen benefit in NSABP-P1. Breast Cancer Res Treat. 2012;133(3):1077-1088.

26. Figuiredo Dias V, Cuppari L, Garcia Lopes MG, et al. Risk factors for hypovitaminosis $\mathrm{D}$ in nondialyzed chronic kidney disease patients. $J$ Ren Nutr. 2012;22(1):4-11

27. Grethen E, Hill KM, Jones R. Serum leptin, parathyroid hormone, 1,25-dihydroxyvitamin $\mathrm{D}$, fibroblast growth factor 23 , bone alkaline phosphatase, and sclerostin relationships in obesity. $J$ Clin Endocrinol Metab. 2012;97(5):1655-1662.

28. Naini AE, Vahdat S, Hedaiati ZP, et al. The effect of vitamin D administration on serum leptin and adiponectin levels in end-stage renal disease patients on hemodialysis with vitamin D deficiency: A placebocontrolled double-blind clinical trial. J Res Med Sci. 2016;21:1.

29. Adams JS, Hewison M. Update in vitamin D. J Clin Endocrinol Metab. 2010;95(2):471-478.

30. Walker GE, Ricotti R, Roccio M, et al. Pediatric obesity and vitamin D deficiency: A proteomic approach identifies multimeric adiponectin as a key link between these conditions. PLoS One. 2014;9(1):e83685.

31. Feng X, Lv C, Wang F. Modulatory effect of 1,25-dihydroxyvitamin D3 on IL1 -induced RANKL, OPG, TNF- $\alpha$ and IL-6 expression in human rheumatoid synoviocyte MH7A. Clin Dev Immunol. 2013;2013:160123.
32. Breslavsky A, Frand J, Matas Z, et al. Effect of high doses of vitamin $\mathrm{D}$ on arterial properties, adiponectin, leptin and glucose homeostasis in type 2 diabetic patients. Clin Nutr. 2013;32(6):970-975.

33. Vélayoudom Céphise FL, Larifla L, Donnet JP, et al. Vitamin D deficiency, vitamin D receptor gene polymorphisms and cardiovascular risk factors in caribbean patients with type 2 diabetes. Diabetes Metab. 2011;37(6):540-545.

34. Yu JR, Lee SA, Lee JG, et al. Serum vitamin d status and its relationship to metabolic parameters in patients with type 2 diabetes mellitus. Chonnam Med J. 2012;48(2):108-115.

35. Yiu YF, Yiu KH, Siu CW, et al. Randomized controlled trial of vitamin D supplement on endothelial function in patients with type 2 diabetes. Atherosclerosis. 2013;227(1):140-146.

36. Patel P, Poretsky L, Liao E. Lack of effect of subtherapeutic vitamin D treatment on glycemic and lipid parameters in Type 2 diabetes: a pilot prospective randomized trial. J Diabetes. 2010;2(1):36-40.

37. Al Zahrani MK, Elnasieh AM, Alenezi FM, et al. A 3-month oral vitamin D supplementation marginally improves diastolic blood pressure in Saudi patients with type 2 diabetes mellitus. Int J Clin Exp Med. 2014;7(12):5421-5428

38. Eftekhari MH, Akbarzadeh M, Dabbaghmanesh MH, et al. The effect of calcitriol on lipid profile and oxidative stress in hyperlipidemic patients with type 2 diabetes mellitus. ARYA Atheroscler. 2014;10(2):82-88. 